\title{
EVALUASI MICROTEACHING TERINTEGRASI MEDIA SOSIAL
}

\author{
Apri Nuryanto \\ Jurusan Pendidikan Teknik Mesin Fakultas Teknik Universitas Negeri Yogyakarta \\ Email: apri_nuryanto@uny.ac.id
}

\begin{abstract}
This study aims to evaluate the implementation of social media-integrated microteaching, viewing it from the effectiveness, efficiency and practicality aspects. This research is a quantitative descriptive study. The data collection methods used is using instruments that were distributed to students undertaking social media-integrated microteaching course. The population in this study were 15 students as respondents. The evaluation results showed an effectiveness level of 91.15, efficiency of 91.43, and practicality of 94.44 .
\end{abstract}

Keywords: evaluation, microteaching, social media integrated

\begin{abstract}
ABSTRAK
Penelitian ini bertujuan untuk mengetahui evaluasi pelaksanaan microteaching yang diintegrasikan dengan media sosial yang dilihat dari efektifitas, efisiensi dan kepraktisan microteaching yang diintegrasikan dengan media sosial. Penelitian ini termasuk penelitian kuantitatif. Metode yang digunakan dengan menggunakan instrument yang dibagikan kepada mahasiswa yang mengambil matakuliah microteaching yang diintegrasikan dengan media sosial. Responden ada sebanyak 15 mahasiswa. Hasil penelitian menunjukkan tingkat efektivitas sebesar 91,15 , efisiensi sebesar 91,43 dan kepraktisan sebesar 94,44.
\end{abstract}

Kata kunci: evaluasi, microteaching, media sosial

\section{PENDAHULUAN}

Evaluasi merupakan kegiatan yang tidak bisa dihindarkan jika ingin melihat apakah suatu proses itu berhasil apa tidak. Evaluasi adalah proses menentukan nilai atau signifikansi, dan evaluasi merupakan produk dari suatu proses (Scriven, 1991:53). Evaluasi dilakukan dalam berbagai bidang salah satunya dalam bidang pendidikan.

Pendidikan tidak terlepas dari adanya seorang guru. Guru mempunyai tugas pokok sebagai tenaga professional dalam hal mendidik, mengajar, mebimbing, mengarahkan, melatih, menilai, dan mengevaluasi peserta didik sesuai dengan Permendikbud No.15 Tahun 2018. Untuk menghasilkan seorang guru yang baik perlu untuk didik dan dilatih dengan baik. Salah satu matakuliah untuk membentuk calon guru yang baik adalah microteaching.

Matakuliah microteaching atau pengajaran mikro dalam penyelenggaraannya diatur melalui pedoman yang disusun oleh Tim
UPPL (2016) akan membentuk kompetensi mahasiswa dalam bagaimana mengajar. Microteaching akan memberikan kesempatan untuk belajar beberapa keterampilan yang penting untuk mengajar dalam waktu singkat. Ini adalah pengalaman yang berguna untuk belajar bagaimana untuk mewujudkan tujuan pengajaran melalui model perencanaan pelajaran. Ini menunjukkan bagaimana persiapan, organisasi, dan presentasi yang penting dalam pembelajaran peserta didik. Memilih kegiatan, menempatkan mereka dalam urutan logis, melakukan perbaikan dalam keseluruhan materi. Menerima umpan balik langsung merupakan sarana untuk meningkatkan produktivitas dan meningkatkan kemampuan strategi mengajar. Dengan mengajukan pertanyaan yang tepat, lingkungan belajar yang kuat dapat dibangun. Selain itu memungkinkan untuk mengajukan pertanyaan pada tingkat kesulitan yang beragam. Microteaching memungkinkan untuk menciptakan lingkungan yang melibatkan 
proses berpikir dan interaksi secara berbeda (Gee, 1992).

Mohan (2007) berpendapat bahwa microteaching adalah salah satu metode yang memungkinkan guru untuk berlatih keterampilan dengan mengajarkan pelajaran yang pendek dengan sejumlah murid yang kecil. Waktu yang diperlukan 5-10 menit, penilaian diberikan oleh supervisor dengan menggunakan panduan penilaian, pelajaran didiskusikan guru dan murid.

Banyak model microteaching yang telah dikembangkan, salah satunya adalah penelitian tentang pengembangan model microteaching terintegrasi dengan media sosial (Nuryanto, 2017). Pada penelitian itu telah dikembangkan model microteaching yang diintegrasikan dengan media sosial. Media sosial yang digunakan adalah facebook. Facebook berfungsi untuk komunikasi, mengunggah materi, RPP, media dan video rekaman mengajar. Sehingga dengan integrasi ini calon guru bisa dipantau kemajuan dalam mengajarnya.

Penelitian penggunaan facebook untuk pembelajaran sudah mulai dilakukan seperti penelitian yang dilakukan oleh Pempek, Yermolayeva, \& Calvert (2009) tentang penggalian informasi penggunaan situs jejaring sosial yang meneliti berapa banyak, mengapa, dan bagaimana menggunakan situs jejaring sosial. Hasil penelitian menunjukkan bahwa rata-rata 30 menit dalam sehari aktivitas digunakan pada facebook. Mahasiswa lebih banyak mengamati konten daripada benarbenar memposting konten. Facebook merupakan media sosial yang paling sering digunakan daripada yang lain. Ekspresi identitas pribadi ditandai melalui agama, ideologi politik, dan pekerjaan.

Hasil penelitian yang dilakukan Hew (Hew, 2011) tentang penggunaan facebook yang digunakan oleh mahasiswa dan dosen. Tujuan penelitian tersebut tidak hanya membahas penggunaan media sosial untuk tujuan pembelajaran akan tetapi juga melihat secara lengkap berbagai aspek dari penggunaan facebook. Topik utama penelitian ini adalah melihat tingkat penggunaan facebook, motif dalam menggunakan facebook, efek dari penggunaan facebook, dan sikap dalam penggunaan facebook. Hasil penelitian ini menyimpulkan bahwa penggunaan facebook untuk keperluan pendidikan masih sangat sedikit, siswa dalam menggunakan facebook hanya untuk keperluan berhubungan dengan orang yang dikenal, dan siswa lebih cenderung mengungkapkan informasi yang lebih pribadi. Penelitian Smock, Ellison, Lampe, \& Wohn (2011) tentang motivasi dalam menggunakan facebook. Hasil penelitian menunjukkan ada perbedaan motivasi dalam penggunaan fiturfitur yang ada di situs, hal ini akan berimplikasi secara teoritis maupun metodologis.

Penilaian dalam rangkaian pengajaran mikro meliputi penilaian terhadap mahasiswa pada saat mengikuti kegiatan: (1) orientasi dan observasi; (2) penyusunan RPP; dan (3) praktik pengajaran mikro. Pada saat mahasiswa praktik pengajaran mikro terbatas, ada tiga aspek yang dinilai yaitu kompetensi pedagogik, kompetensi kepribadian dan kompetensi sosial. Instrumen yang digunakan dalam kegiatan penilaian ini berupa lembar penilaian yang dipergunakan oleh dosen pembimbing pengajaran mikro.

Pembobotan penilaian pengajaran mikro menurut (Tim UPPL, 2016 : 32) adalah sebagai berikut:

Tabel 1. Pembobotan Penilaian Microteaching

\begin{tabular}{llc}
\hline No & Komponen & Bobot \\
\hline 1 & Orientasi dan observasi & 1 \\
2 & RPP & 2 \\
3 & Praktik microteaching & 4 \\
4 & kompetensi kepribadian & 2 \\
5 & kompetensi sosial & 1 \\
\hline
\end{tabular}

Pada penelitian ini untuk melihat hasil evaluasi pada pelaksanaan microteaching yang diintegrasikan dengan media sosial yang dinilai berdasarkan efektifitas, efisiensi dan kepraktisannya. 


\section{METODE}

Penelitian ini termasuk dalam penelitian deskriptif kuantitatif. Instrumen yang digunakan berupa angket yang diberikan kepada peserta kuliah microteaching yang terintegrasi media sosial sebanyak 15 mahasiswa. Selain itu untuk konfirmasi digunakan lembar pengamatan untuk melihat hasil rekaman video mengajar yang ada di group media sosial. Data dianalisis secara kuantitatif dan disajikan dalam grafik dan tabel.

\section{HASIL DAN PEMBAHASAN}

Hasil penelitian evaluasi dilihat dari aspek efektivitas, efisiensi dan kepraktisannya disajikan sebagai berikut.

Data penelitian terhadap efektivitas model microteaching terintegrasi media sosial yang dikembangkan disajikan dalam Tabel 2 dan Gambar 1 sebagai berikut.

Tabel 2. Hasil Efektivitas Model

\begin{tabular}{|c|c|c|c|}
\hline \multirow[b]{2}{*}{ No } & \multirow[b]{2}{*}{ Indikator } & \multicolumn{2}{|c|}{ Rata-rata } \\
\hline & & Skala 5 & $\begin{array}{c}\text { Skala } \\
100\end{array}$ \\
\hline 1 & $\begin{array}{l}\text { Pengintegrasian media jejaring sosial dalam microteaching memberikan pengaruh yang } \\
\text { baik }\end{array}$ & 4,40 & 88,00 \\
\hline 2 & Terjadi perbaikan dalam menyusun RPP & 4,33 & 86,67 \\
\hline 3 & Peningkatan Kompetensi dasar mengajar terbatas & 4,33 & 86,67 \\
\hline 4 & Peningkatan Kompetensi dasar mengajar terpadu & 4,60 & 92,00 \\
\hline 5 & Materi yang di-upload di media jejaring sosial mendukung peningkatan kompetensi & 4,87 & 97,33 \\
\hline 6 & Mahasiswa dapat melakukan refleksi lebih baik & 4,60 & 92,00 \\
\hline 7 & Mahasiswa dapat melakukan remidi & 4,47 & 89,33 \\
\hline 8 & $\begin{array}{l}\text { Mahasiswa dapat melakukan komentar dan penilaian secara online di media jejaring } \\
\text { sosial }\end{array}$ & 4,87 & 97,33 \\
\hline 9 & $\begin{array}{l}\text { Pencapaian kompetensi dasar mengajar dengan waktu yang disediakan dalam praktik } \\
\text { mengajar di kelas }\end{array}$ & 4,47 & 89,33 \\
\hline 10 & Peningkatan partisipasi secara aktif dari mahasiswa & 4,67 & 93,33 \\
\hline \multirow[t]{2}{*}{11} & $\begin{array}{l}\text { Model yang dikembangkan dengan media jejaring sosial bermanfaat dalam mencapai } \\
\text { tujuan pembelajaran microteaching }\end{array}$ & 4,53 & 90,67 \\
\hline & Rata-rata & 4,56 & 91,15 \\
\hline
\end{tabular}

Berdasarkan dari data yang diperoleh dari efektivitas model hasil penelitian menunjukkan bahwa rata-rata skor sebesar 4,56 atau 91,15 dalam skala 100. Hasil efektivitas terbesar pada indikator dukungan terhadap peningkatan kompetensi dan kemudahan dalam kemudahan pemberian komentar secara online sebesar 4,87. Sedangkan indikator yang terendah pada terjadinya perbaikan dalam penyusunan RPP dan Peningkatan kompetensi dasar terbatas dengan skor sebesar 4,33 atau 86,67 dalam skala 100. Walaupun pada indikator tersebut masih rendah akan tetapi hasil skor menunjukkan sudah baik karena sudah lebih besar dari 85 dalam skala 100 . Secara lebih jelas data tentang efektivitas model data disajikan dalam Gambar 1. 


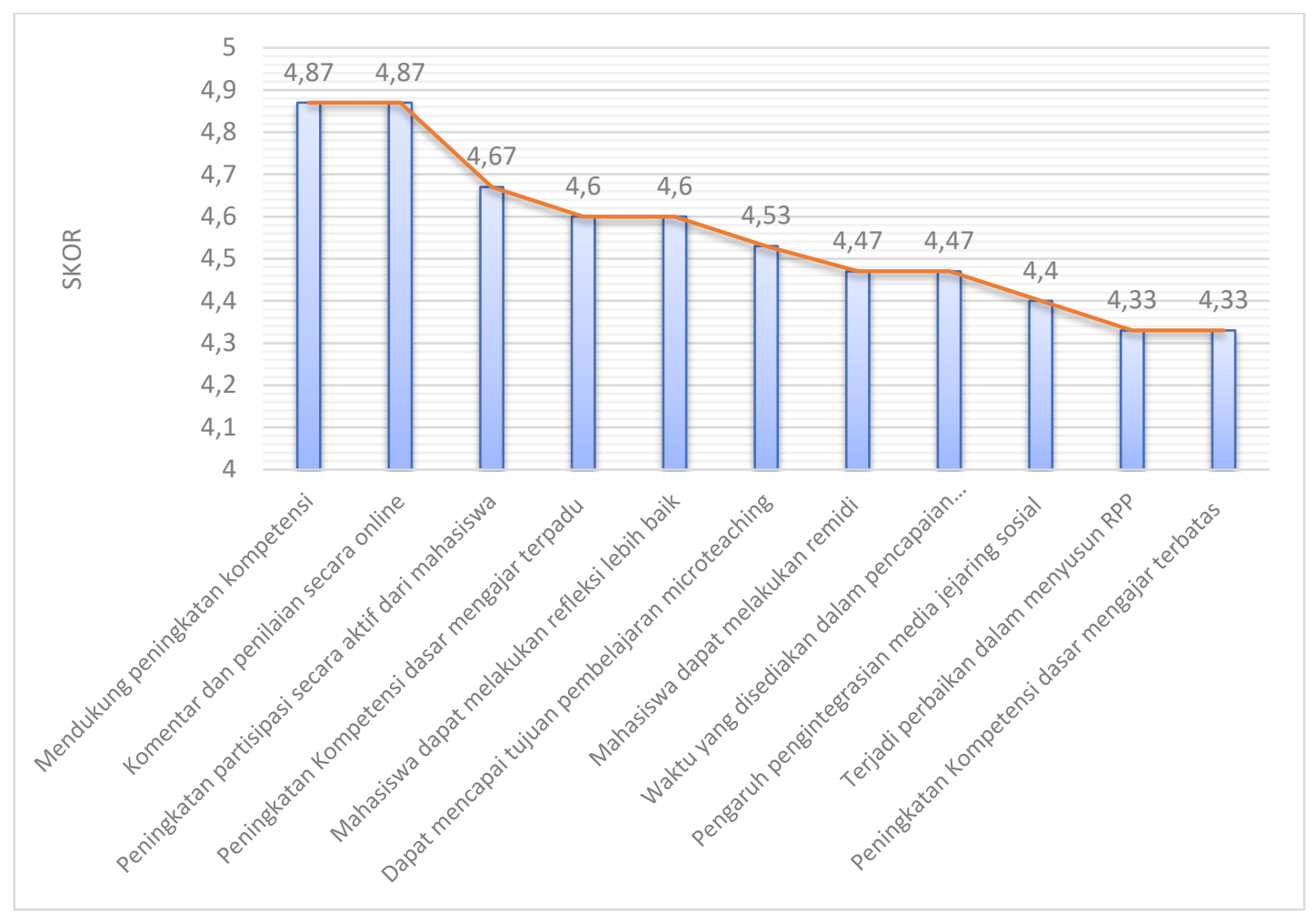

Gambar 1. Hasil Efektivitas microteaching terintegrasi media sosial

Data hasil penelitian tentang efisiensi model microteaching yang terintegrasi dengan media jejaring sosial disajikan dalam Tabel 3 dan Gambar 2. Berdasarkan data penelitian yang diperoleh bahwa efisiensi model didapatkan skor sebesar 4,57 atau 91,43 dalam skala 100.

Secara lebih rinci untuk indikator yang terbesar dari hasil efisiensi model adalah pada indikator waktu presentasi di kelas jadi bertambah banyak dan pelaksanaan microteaching dapat berjalan dengan optimal dengan nilai 4,73 atau 94,67 dalam skala 100 . Sedangkan indikator yang rendah yaitu pada biaya tambahan yang dikeluarkan mahasiswa relatif sedikit yaitu sebesar 4,20. Dengan demikian responden masih menganggap bahwa model ini memerlukan tambahan biaya yang lebih dibanding dengan model sebelumnya. Walaupun demikian skor nilai sudah lumayan baik karena skor sudah 84 dalam skala 100 .

Tabel 3. Hasil Efisiensi Model

\begin{tabular}{llcc}
\hline \multirow{2}{*}{ No } & \multicolumn{1}{c}{ Indikator } & \multicolumn{2}{c}{ Rata-rata } \\
\cline { 3 - 4 } & & Skala 5 & Skala \\
& & & 100 \\
\hline 1 & Pengintegrasian media jejaring sosial dapat menghemat waktu pembelajaran di & 4,47 & 89,33 \\
& dalam kelas & & \\
2 & Jumlah presentasi di kelas jadi bertambah banyak & 4,73 & 94,67 \\
3 & Pelaksanaan microteaching dapat berjalan dengan optimal & 4,73 & 94,67 \\
4 & Dapat dilaksanakan sesuai program yang ada sebelumnya & 4,47 & 89,33 \\
5 & Biaya tambahan yang dikeluarkan mahasiswa relatif sedikit & 4,20 & 84,00 \\
6 & Dapat diakses ke berbagai media (komputer, tablet atau HP) & 4,73 & 94,67 \\
7 & Mahasiswa dapat belajar secara mandiri & 4,67 & 93,33 \\
\hline & $\quad$ Rata-rata & 4,57 & 91,43 \\
\hline
\end{tabular}




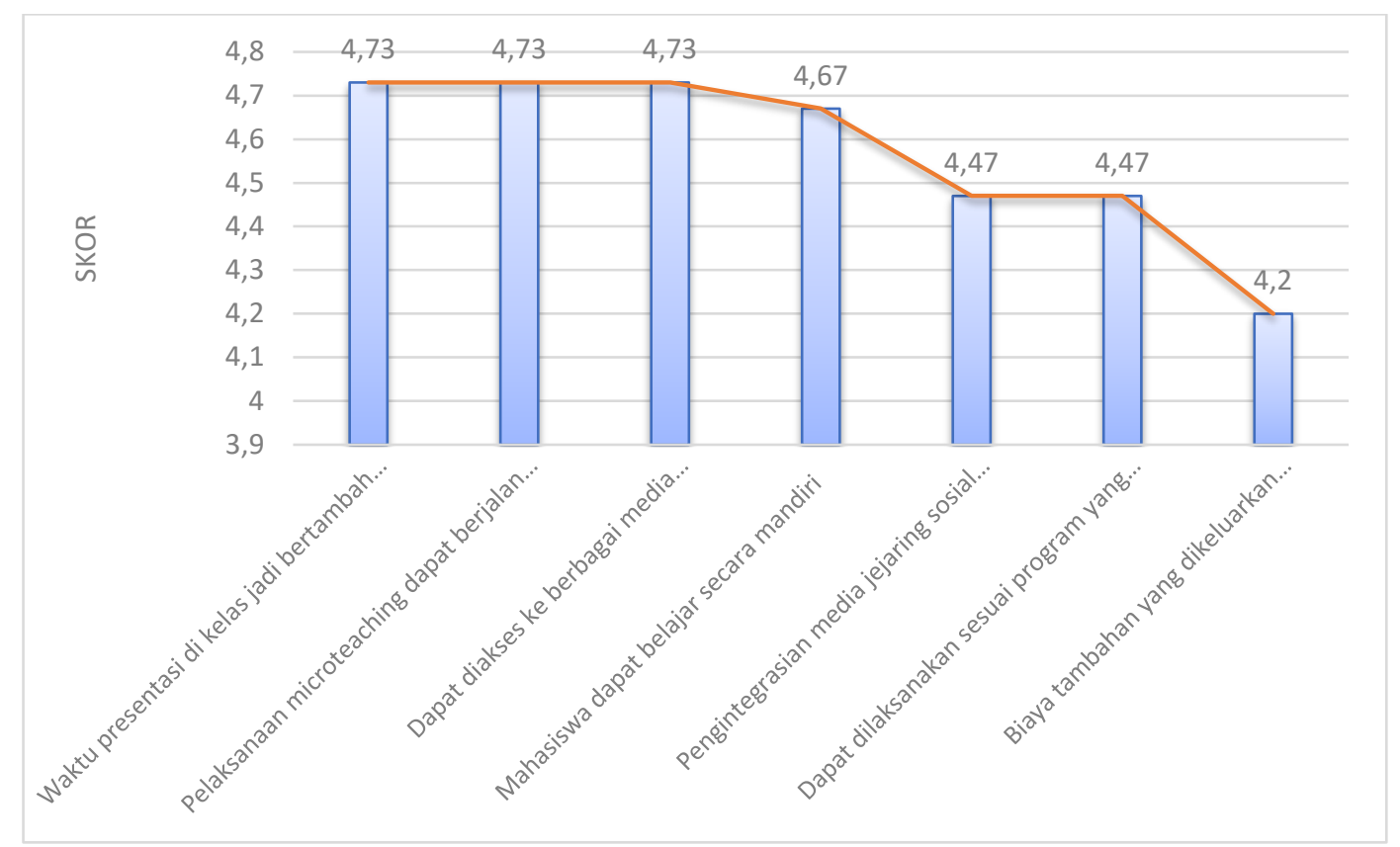

Gambar 2. Hasil efisiensi model

Hasil tanggapan responden terhadap kepraktisan model yang dikembangkan disajikan dalam Tabel 4 dan Gambar 3. Dari data di atas terlihat rata-rata hasil kepraktisan model sebesar 4,72 atau sebesar 94,44 dalam skala 100. Indikator terbesar dari hasil kepraktisan model pada kemudahan dosen dalam melakukan penilaian $(4,93)$ dan indikator terendah pada kemudahan melakukan perencanaan pembelajaran $(4,6)$.

Tabel 4. Hasil Kepraktisan Model

\begin{tabular}{|c|c|c|c|}
\hline \multirow[b]{2}{*}{ No } & \multirow[b]{2}{*}{ Indikator } & \multicolumn{2}{|c|}{ Rata-rata } \\
\hline & & Skala 5 & $\begin{array}{c}\text { Skala } \\
100\end{array}$ \\
\hline 1 & $\begin{array}{l}\text { Model microteaching terintegrasi dengan media jejaring sosial mudah dan } \\
\text { praktis untuk dilaksanakan }\end{array}$ & 4,67 & 93,33 \\
\hline 2 & Mahasiswa dapat melakukan model yang dikembangkan dengan mudah & 4,67 & 93,33 \\
\hline 3 & Mudah untuk melakukan perencanaan pembelajaran & 4,60 & 92,00 \\
\hline 4 & Mudah untuk melakukan komentar di media jejaring sosial & 4,73 & 94,67 \\
\hline 5 & Mudah untuk melakukan penilaian & 4,73 & 94,67 \\
\hline 6 & Dosen mudah untuk melakukan penilaian & 4,93 & 98,67 \\
\hline & Rata-rata & 4,72 & 94,44 \\
\hline
\end{tabular}




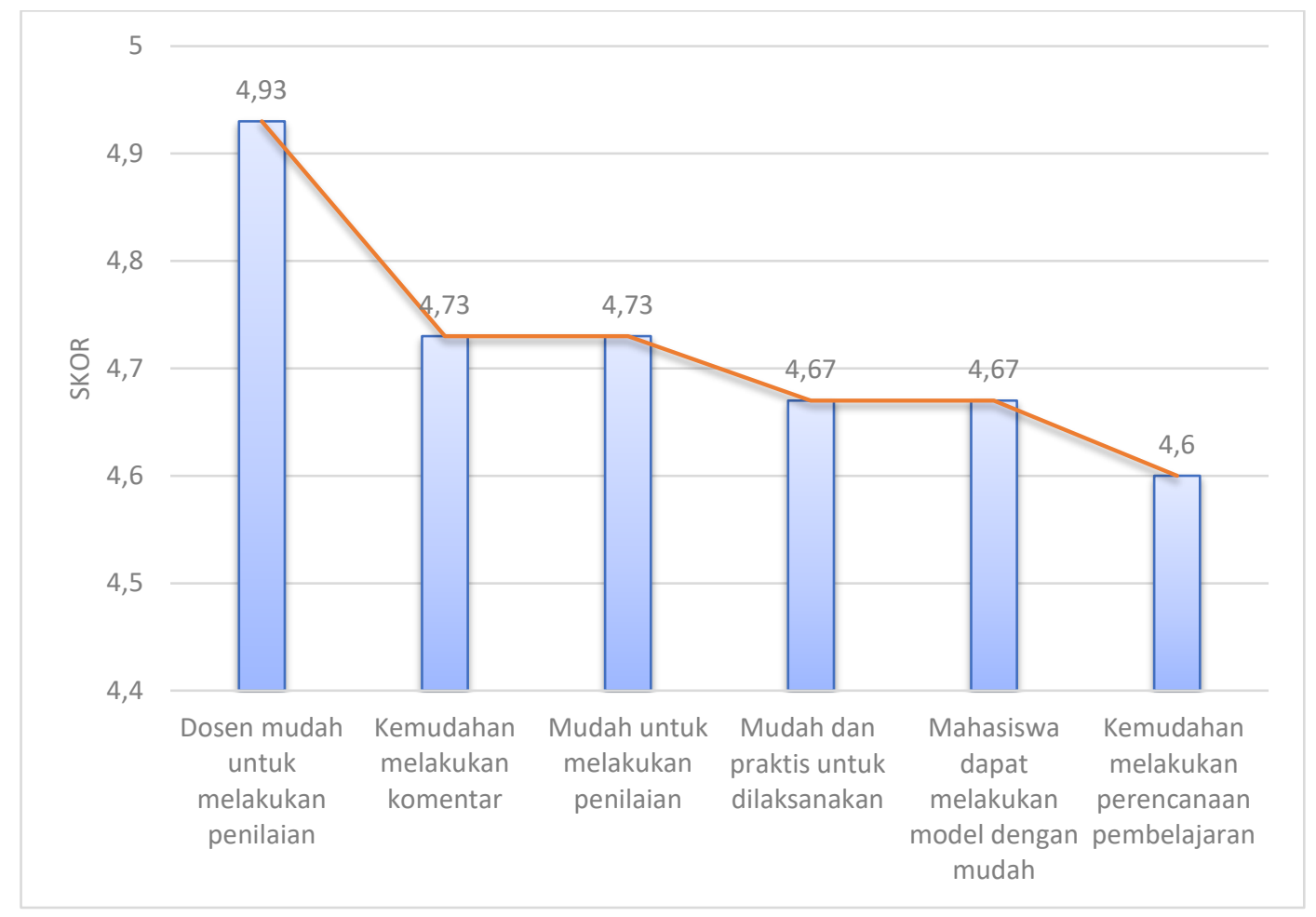

Gambar 3. Hasil Kepraktisan Model

Analisis hasil evaluasi microteaching terintegrasi media sosial dilihat dari segi efektivitas, efisiensi dan kepraktisan model. Hasil efektivitas dari model secara umum didapatkan nilai sebesar 4,56 atau 91,15 pada skala 100. Hasil efektivitas ini sudah menunjukkan bahwa model microteaching terintegrasi media sosial yang dibuat sudah efektif untuk digunakan. Penilaian yang terbesar dari diterapkan model ini adalah pada indikator untuk peningkatan kompetensi dan kemampuan mahasiswa dalam melakukan penilaian secara online di media sosial dengan nilai 97,33.

Hasil akhir dari efisiensi model dari hasil penelitian didapatkan hasil sebesar 91,43. Hasil ini sudah baik dan penilaian efisiensi tertinggi dalam hal: (1) waktu presentasi yang bertambah banyak; (2) pelaksanaan microteaching berjalan optimal; dan (3) kemudahan diakses dengan berbagai media. Dengan penerapan model microteaching terintegrasi media sosial presentasi yang dilakukan mahasiswa meningkat menjadi $120 \%$ hal ini sangat efisien. Peningkatan ini disebabkan karena proses pemberian komentar yang biasanya dilaksanakan di kelas dikurangi dan banyak dilakukan di media jejaring sosial facebook. Optimalisasi pelaksanaan microteaching terlihat dari hampir semua kompetensi mengajar terbatas dan terpadu dapat dipraktikkan, sehingga kemampuan mahasiswa lebih meningkat. Hal juga terlihat dari setiap tampilan yang bisa dilihat di video yang diunggah di media jejaring sosial.

\section{SIMPULAN}

Simpulan dari penelitian yang dilakukan adalah sebagai berikut: evaluasi microteaching terintegrasi media sosial dilihat dari aspek efektivitas sebesar 91,15 
sehingga model ini sudah sangat efektif. Dari aspek efisiensi terlihat sudah sangat efisien mendapat hasil 91,43, dan skor kepraktisan sebesar 94,44 sehingga sudah praktis untuk digunakan.

\section{DAFTAR RUJUKAN}

Gee, J. B. (1992). Innovation in instructional strategies used with graduate. Knoxville: The MidSouth Education Research Association.

Hew, K. F. (2011). Students' and teachers' use of facebook. Computers in Human Behavior 27, 662-676.

Kementrian pendidikan dan Kebudayaan (2018), Perturan Menteri Pendidikan dan Kebudayaan Republik Indonesia Nomor 15, Tahun 2018, Tentang Pemenuhan Beban Kerja Guru, Kepala Sekolah, dan Pengawas Sekolah, Jakarta: Depdiknas.

Mohan, R. (2007). Innovative science teaching for physical science teachers, 3rd ed. New Delhi: Prentice-Hall.

Nuryanto, A. (2017). Pengembangan Model Microteaching Terintegrasi Media Sosial. Yogyakarta: Disertasi Pasca Sarjana UNY.

Scriven, M. (1991). Evaluation thesaurus. Fourth edition. Newbury Park: Sage.

Tim UPPL. (2016). Panduan pengajaran mikro. Yogyakarta: UNY Press.

Pempek, T. A., Yermolayeva, Y. A., \& Calvert, S. L. (2009). College students' social networking experiences on facebook. Journal of Applied Developmental Psychology 30, 227-238.

Smock, A. D., Ellison, N. B., Lampe, C., \& Wohn, D. Y. (2011). Facebook as a toolkit: a uses and gratification approach to unbundling feature use. Computers in Human Behavior 27, 2322-2329. 